\title{
THE NADP+-DEPENDENT GLUTAMATE DEHYDROGENASE OF THE YEAST KLUYVEROMYCES MARXIANUS RESPONDS TO NITROGEN REPRESSION SIMILARLY TO SACCHAROMYCES CEREVISIAE
}

\author{
Marcos Antonio de Morais-Júnior \\ Setor de Biologia Molecular, Laboratório de Imonopatologia Keizo Asami, Departamento de Genética, Universidade Federal de \\ Pernambuco, Recife, PE, Brasil.
}

Submitted: April 04, 2003; Returned to Authors for corrections: July 24, 2003; Approved: September 12, 2003

\begin{abstract}
$\mathrm{NADP}^{+}$-dependent glutamate dehydrogenase ( $\mathrm{NADP}^{+}-\mathrm{Gdh}$ ) is the first step in ammonia assimilation pathway in Saccharomyces cerevisiae and the knowledge of its regulation is the key for many biotechnological purposes such as single cell protein production. The regulation of $\mathrm{NADP}^{+}-\mathrm{Gdh}$ activity in Kluyveromyces marxianus cells was evaluated under different ammonia supply in batch cultivations. The results showed that $K$. marxianus $\mathrm{NADP}^{+}-\mathrm{Gdh}$ activity is induced over a narrow range of extracellular ammonia supply, being repressed by both high ammonia concentration and the glutamate formed. This activity is not growth-associated and may function mainly to trace low amounts of ammonia after growth cessation. The results demonstrated that $\mathrm{NADP}^{+}-\mathrm{Gdh}$ may not be the main enzyme for ammonia assimilation in $K$. marxianus, as it has been postulated for $K$. lactis, instead is subjected to the same regulatory mechanism described for $S$. cerevisiae.
\end{abstract}

Key words: ammonia assimilation, enzyme activity, glutamate dehydrogenase, Kluyveromyces marxianus.

\section{INTRODUCTION}

The availability of intracellular glutamate is essential for the transamination reactions involved in the amino acids biosynthetic pathways. In Saccharomyces cerevisiae cells there are two routes for glutamate formation. The first is considered to be the main glutamate-producing pathway in this yeast. The ammonia uptake from the medium is used to produce glutamate by the amination of 2-oxoglutarate by $\mathrm{NADP}^{+}$-dependent glutamate dehydrogenase (E.C. 1.4.1.4) $\left(\mathrm{NADP}^{+}-\mathrm{Gdh}\right.$ : 2oxoglutarate $+\mathrm{NADPH}+\mathrm{NH}_{4}{ }^{+} \rightarrow$ glutamate $+\mathrm{NADP}^{+}$), followed by the amination of glutamate to glutamine by glutamine synthase (E.C. 6.3.1.2) (Gs: glutamate + ATP $\rightarrow$ glutamine + ADP). In the second, glutamate is also produced in a transamination reaction, which transfers one amino group from glutamine to 2oxoglutarate, catalysed by the glutamate synthase or glutamate2-oxoglutarate aminotransferase (E.C. 1.1.1.13) (Gogat: glutamine +2 -oxoglutarate $+\mathrm{NADH} \rightarrow 2$ glutamate $\left.+\mathrm{NAD}^{+}\right)(9)$. When extracellular ammonia concentration exceed $5 \mathrm{mM}$, S. cerevisiae cells use preferentially NADP ${ }^{+}-G d h$, whereas Gs-Gogat pathway is activated at low ammonia concentrations. On the other hand, Kluyveromyces lactis cells seem to use the Gs-Gogat pathway as the main glutamate biosynthetic pathway $(12,14)$. Although this ATP-consuming pathway is energetically unfavourable, this could be related to the maintenance of redox equilibrium to reoxidise the excess of NADH produced during glycolysis, since ethanolic fermentation does not occur in this yeast under oxygen supply (8).

It has been related the biotechnological use of Kluyveromyces in the "Yeast as Cell Factory" concept to produce amino acidrich biomass due to its advantageous physiological characteristics compared to S. cerevisiae: the absence of ethanol production (Crabtree-negative effect), the lower catabolic repression response, the higher flux through the glycolytic pathway $(8,15)$ and the high capacity of the respiratory enzymes $(6,15)$. The close-related specie Kluyveromyces marxianus has been used

*Corresponding author: Mailing Address: Departamento de Genética, Universidade Federal de Pernambuco. Av. Moraes Rego, s/n. 50670-901, Recife, PE, Brasil. Tel.: (+5581) 2126-8569. Fax: (+5581) 2126-8522. E-mail: morais@lika.ufpe.br 
to produce bioingredients, such as oligopeptides, oligosacharides and oligonucleotides mainly for pharmaceutical and food industries (1). Similarly to K. lactis, K. marxianus is Crabtreenegative yeast, generally regarded as safe for human and animal consumption and possesses an arsenal of hydrolytic extracellular hydrolases that enables its use for bioconversion of complex sugar-rich substrates into single cell protein. There are no reports in the literature regarding enzymes activities and its regulation on the nitrogen assimilation pathways in K. marxianus. Therefore, the necessity to understand those pathways precedes the efforts to produce amino acids-enriched $K$. marxianus biomass. The aim of this work was to study the behaviour of the $\mathrm{NADP}^{+}$-glutamate dehydrogenase activity of $K$. marxianus cells under different batch cultivation conditions. The results showed that the enzyme activity responds to the extracellular concentration of ammonia, being inhibited by high substrate concentrations. Moreover, it seemed to be controlled by the availability of ammonia or by the presence of free amino acids in the medium.

\section{MATERIALS AND METHODS}

\section{Yeast strain and culture condition}

The prototrophic and diploid homothalic $K$. marxianus CBS6556 type strain was used in this work. Cells were maintained freshly in YPD medium and one colony was used to inoculate $50 \mathrm{~mL}$ mineral medium containing $1.7 \mathrm{~g} . \mathrm{L}^{-1}$ yeast nitrogen base (w/o amino acids and ammonium sulfate), 20 g.L. $\mathrm{L}^{-1}$ glucose and $5 \mathrm{~g} . \mathrm{L}^{-1}$ ammonium sulfate. After $16 \mathrm{~h}$ of cultivation, the cells were washed and transferred to a fresh mineral medium containing either glucose, lactose, ethanol or potassium acetate at $1 \%(\mathrm{w} / \mathrm{v})$ as carbon sources or either ammonium sulfate, glutamate, glutamine or leucine at $40 \mathrm{mM}$, based on their molecular weight, as nitrogen souces. The cultures were incubated for further $16 \mathrm{~h}$ in rotating shaker at $30^{\circ} \mathrm{C}$. These cultures were used to inoculate specific mineral media at 1/50 dilution for flask-batch experiments. In $\mathrm{pH}-$ controlled experiments, media cultures were buffered with 10 mM PIPES [Piperazine-N, $\mathrm{N}^{\prime}$-bis (2-ethanesulfonic acid)] at indicated $\mathrm{pH}$ values. Duplicate experiments were performed for each tested culture condition.

\section{Enzyme analysis}

Cell density was accompanied by optical density of the culture at $660 \mathrm{~nm}$. Cell biomass was washed in buffer $(100 \mathrm{mM}$ tris $\mathrm{pH} 7.5$ and $1.5 \%$ triton $\mathrm{X}-100$ ) and suspended in 1/100 initial volume with the same buffer. The cells were broken with acidwashed glass beads with four cycles of $30 \mathrm{~s}$ vortexing and $30 \mathrm{~s}$ on ice. Supernatants were collected and centrifuged for $20 \mathrm{~min}$ at $12,000 \mathrm{~g}$ to remove cell debris. The cell-free extracts were used for enzyme activity as described by Norkrans and TunbladJohansson (10). One enzyme unit (U) is the amount of protein capable of oxidazing $1 \mu \mathrm{mol} \mathrm{NADPH} / \mathrm{min}$ at $30^{\circ} \mathrm{C}$. For very low enzyme activity, milli-unit (mU; $\left.10^{-3} \mathrm{U}\right)$ was used. Protein concentration was measured by the Folin-Ciocateau method (9). Enzyme specific activity referred to the amount of enzyme units per milligram of protein in the cell free extract. Residual glucose concentration in the supernatants was determined by the Dinitrosalisilic acid method (10), while residual ammonium concentration was measured according to Cataldo et al. (11). All reagents were purchased from Sigma-Aldrich Co.

\section{Chemicals}

Commercial YNB, yeast extract and peptone are from Difco Co. (Detroit, USA). Glucose and lactose are from Vetec (Rio de Janeiro, Brazil). Ethanol is from Merck S.A. (Rio de Janeiro, Brazil). Ammonium sulfate, amino acids, PIPES, potassium acetate and the chemicals for enzyme activity and protein, glucose and ammonia determinations are from Sigma-Aldrich Co. (St. Louis, USA).

\section{RESULTS AND DISCUSSION}

Cells of $K$. marxianus CBS6556 were batch cultivated in mineral medium containing glucose and ammonium sulfate as carbon and nitrogen sources, respectively, and the calculated maximum specific growth rate of $0.4 \mathrm{~h}^{-1}$. During this period a very low NADP $\mathrm{NAdh}^{+}$activity $\left(<10 \mathrm{mU} \cdot \mathrm{mg}^{-1}\right)$ was detected in cell-free extract (Fig. 1). However, when the residual ammonium

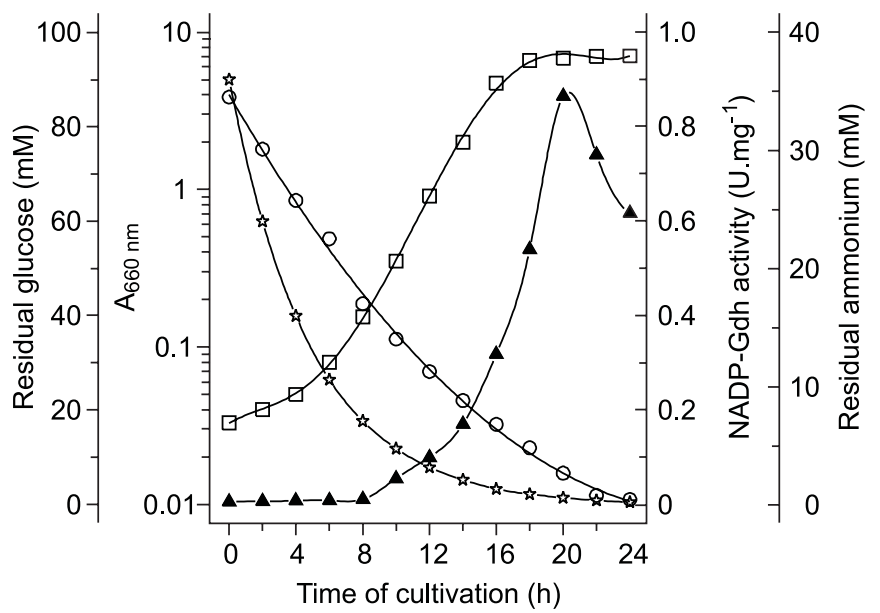

Figure 1. Flask-batch cultivation profile of Kluyveromyces marxianus CBS6556 grown in mineral medium containing 90 $\mathrm{mM}$ glucose $\left(16 \mathrm{~g} . \mathrm{L}^{-1}\right)$ and $38 \mathrm{mM}$ ammonium sulfate $\left(5 \mathrm{~g} . \mathrm{L}^{-1}\right)$ as carbon and nitrogen sources, respectively. Symbols represent optical density at $660 \mathrm{~nm}(\square)$, glucose consumption $(\bigcirc)$, ammonium consumption ( $凵$ ( ) and $\mathrm{NADP}^{+}$-Gdh specific activity $(\boldsymbol{\Delta})$. Each value represents the mean of two independent experiments. 
concentration decreased below $8 \mathrm{mM}$ it was possible to detect $\mathrm{NADP}^{+}-\mathrm{Gdh}$ activity in cell-free extracts, reaching a peak of $0.88 \mathrm{U} \cdot \mathrm{mg}^{-1}$ at $20 \mathrm{~h}$ of cultivation with low availability of ammonium $(<0.6 \mathrm{mM})$ to sustain cell growth (Fig. 1). The decrease in the enzyme activity thereafter may be explained by the inability of NADP+-Gdh to trace the low level of intracellular ammonium. This result suggests that, similarly to $S$. cerevisiae, K. marxianus $\mathrm{NADP}^{+}-\mathrm{Gdh}$ activity primary functions to assimilate ammonium when its extracellular concentration is in a very narrow range.

The effect of initial ammonium concentration in the medium on the $\mathrm{NADP}^{+}-\mathrm{Gdh}$ activity was tested after growing yeast cells for $16 \mathrm{~h}$ as shown in Fig. 2. The highest enzyme activity was detected for cultures starting with $40 \mathrm{mM}$ ammonium sulfate, which according to the fermentative profile in Fig. 1 should contain around $1 \mathrm{mM}$ at $16 \mathrm{~h}$ of cultivation. The lower the concentration of ammonium sulfate at the beginning of cultivation, the lower enzyme activity was detected in cell-free extracts (Fig. 2). However, a short-term induction of the enzyme activity was observed $15 \mathrm{~min}$ after the addition of ammonium sulfate even at such low concentration of $0.5 \mathrm{mM}$ in the medium (Fig. 2, insert). Additionally, cells cultivated at the highest initial

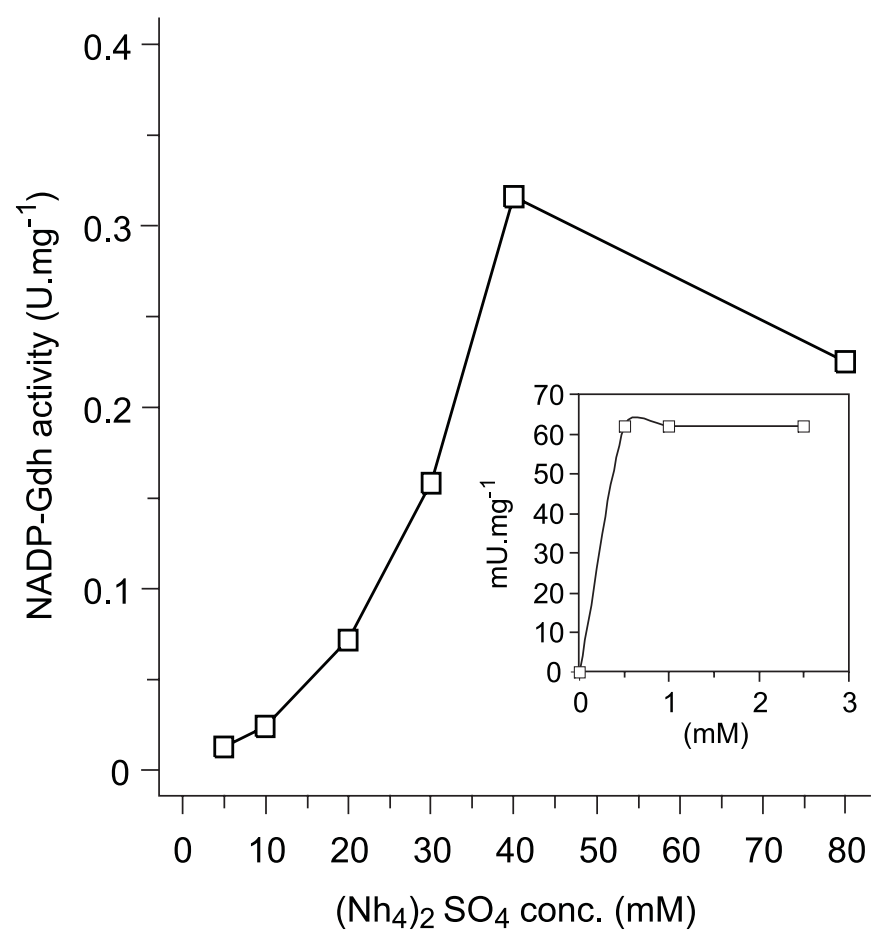

Figure 2. $\mathrm{NADP}^{+}-\mathrm{Gdh}$ specific activity of protein extracts from K.marxianus CBS6556 cells grown for $16 \mathrm{~h}$ in mineral medium containing $90 \mathrm{mM}$ glucose and different ammonium sulfate concentrations. The insert represents the rapid induction of $\mathrm{NADP}^{+}$-Gdh activity $15 \mathrm{~min}$ after ammonium sulfate addition. Each value represents the mean of two independent experiments. ammonium sulfate concentration $(80 \mathrm{mM})$ showed the lowest enzyme activity (Fig. 2). A similar effect was observed for $S$. cerevisiae cells upon cultivation in external ammonium concentrations above $50 \mathrm{mM}$ (3). In that case, the highest enzyme activity was detected at $24 \mathrm{mM}$ ammonium sulfate, decreasing for higher ammonium sulfate concentrations. Bongonez et al. (3) showed that intracellular ammonium concentration increased in the presence of increasing extracellular ammonium concentrations, which could be involved in the decreasing of enzyme activity in S. cerevisiae cells. Moreover, steady-state $S$. cerevisiae cells showed higher $\mathrm{NADP}^{+}-\mathrm{Gdh}$ activity at higher dilution rates, as a consequence of the decrease in the residual ammonia concentration in the supernatant (13). This effect of initial ammonium concentration on the $K$. marxianus $\mathrm{NADP}^{+}$Gdh activity was followed along the cellular growth. In cultures with $10 \mathrm{mM}$ initial ammonium sulfate, the $\mathrm{NADP}^{+}-\mathrm{Gdh}$ activity exponentially increased up to $8 \mathrm{~h}$ of cultivation, followed with a decrease caused probably by nitrogen depletion in the medium (Fig. 3). Nonetheless, cultures with $40 \mathrm{mM}$ initial ammonium sulfate showed biphasic behaviour with a linear increase for the first $4 \mathrm{~h}$ followed by an exponential increase.

An alternative way for testing the effect of ammonium concentration on the enzyme activity is to induce its intracellular

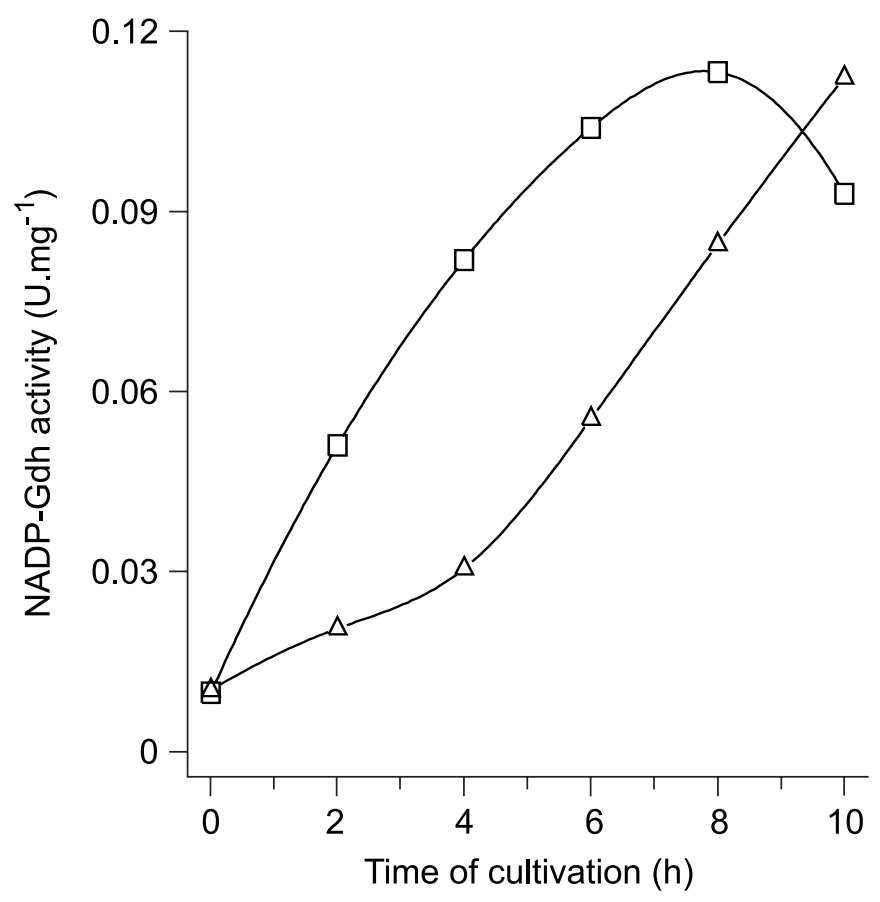

Figure 3. Kinetics of $\mathrm{NADP}^{+}-\mathrm{Gdh}$ activity along cultivation of K.marxianus CBS6556 cells in mineral medium containing 90 $\mathrm{mM}$ glucose in the presence of $10 \mathrm{mM}(\square)$ or $40 \mathrm{mM}(\triangle)$ ammonium sulfate. Each value represents the mean of two independent experiments. 
accumulation. Ammonium uptake operates in yeast at very narrow $\mathrm{pH}$ range (5.5-7.5) (5). At low $\mathrm{pH}$, ammonium ion $\left(\mathrm{NH}_{4}{ }^{+}\right)$ formation is favoured and in yeast cells ammonium uptake is mediated by an $\mathrm{H}^{+}$-antiport transport systems at expenses of ATP (1 ATP per mol of $\mathrm{NH}_{4}^{+}$). This explains the medium acidification observed when growing yeast cell on glucose and ammonium salt. However, at higher $\mathrm{pH}$ the ammonia $\left(\mathrm{NH}_{3}\right)$ formed accumulates in growing cells essentially by diffusion process (3). This methodology was used for further verification of the effect of high ammonium concentration on NADP+-Gdh activity. Cell cultivations were carried out in buffered mineral medium and the results are presented in Table 1 . $\mathrm{NADP}^{+}-\mathrm{Gdh}$ activity decreased 6- and 10-fold when $\mathrm{pH}$ of medium was buffered at 5 or 7.5, respectively, comparing to a non-buffered condition. Bogonez et al. (3) observed a 10-fold increase in intracellular ammonia concentration of $S$. cerevisiae cells when medium $\mathrm{pH}$ was maintained at 5 , which was followed by a 2 fold decrease in $\mathrm{NADP}^{+}$-Gdh activity. That decreasing in the enzyme activity was even higher by raising medium $\mathrm{pH}$ to 7 . Our results indicate that $K$. marxianus $\mathrm{NADP}^{+}-\mathrm{Gdh}$ also negatively responds to the increasing in intracellular ammonium concentration.

The effects of different carbon sources on the NADP+Gdh activity were also evaluated. K. marxianus cells showed significantly lower specific growth rate on ethanol when comparing to glucose (Table 2), which were practically the same

Table 1. Effect of medium $\mathrm{pH}$ on the $\mathrm{NADP}^{+}$-Gdh activity of K.marxianus CBS6556 cells.

\begin{tabular}{cccc}
\hline Buffering $^{\mathrm{a}}$ & Initial $\mathrm{pH}$ & $\begin{array}{c}\mathrm{pH} \text { of medium } \\
\text { at harvest }\end{array}$ & $\begin{array}{c}\mathrm{NADP}^{+}-\mathrm{Gdh} \\
\left(\mathrm{U}_{\mathrm{mg}}{ }^{-1}\right)\end{array}$ \\
\hline Yes & 7.5 & 7.0 & 0.03 \\
Yes & 5.0 & 5.0 & 0.05 \\
No & 6.3 & 3.8 & 0.31 \\
\hline
\end{tabular}

${ }^{a}$ Cells were cultivated for $16 \mathrm{~h}$ in mineral media containing 90 $\mathrm{mM}$ glucose and $40 \mathrm{mM}$ ammonium sulfate, buffered (yes) or not (no) at the begining of cultivation with $10 \mathrm{mM}$ Pipes-HCl. Each value represents the mean of two independent experiments. values found for shake flask cultivation of $K$. lactis cells in both carbon sources (8). No effect on the cell growth was observed for lactose media. For cultivation on either glucose (respiro-fermentative carbon source) or ethanol (fully respiratory carbon source) no difference on the enzyme activity was observed (Table 2), suggesting that the enzyme is not subjected to glucose repression. On the other hand, the use of acetate as the single carbon source promoted a 3 -fold decreased in the specific growth rate and a 10 -fold decrease in the NADP+ Gdh activity (Table 2). These effects were also observed for $S$. cerevisiae cells (3). This raises two possible explanations: growth-association or substrate-repression. The dependence of the $\mathrm{NADP}^{+}-\mathrm{Gdh}$ activity on the growth rate could be discharged by the enzyme kinetics as shown in the Fig. 1 and the values attained on ethanol. A long-term exposure to high ammonium concentration, with consequent raising in the intracellular ammonium, seems therefore to be a better explanation. Contrary to found in the present paper (Fig. 1), $\mathrm{NADP}^{+}-\mathrm{Gdh}$ activity of $K$. lactis cells grown in mineral medium was higher at the beginning of cultivation and decreased along the cell growth (14)

Finally, it was investigated whether the same nitrogenregulatory mechanism that takes place in $S$. cerevisiae can be applied for K. marxianus. A 3.5-fold reduction of the NADP+Gdh activity was observed for cells growing on glutamate, followed by 2 -fold decrease in leucine and 1.8 -fold decrease in glutamine, when compared to ammonia-growing cells (Table 2). However, glutamine seems to repress $G D H 1$ gene expression more severely in $S$. cerevisiae cells than glutamate $(7,13)$, while leucine promoted a 2 -fold repression in the gene expression (7). The excess of leucine acts by repressing the enzymes of its first biosynthetic pathway, impairing $\alpha$-isopropylmalate formation. This compound is essential for inducing Leu3p activator protein to binding $\mathrm{UAS}_{\mathrm{LEU}}$ element in the promotor region of $G D H 1$ gene. Therefore, this gene is less induced in leucine-growing $S$. cerevisiae cells (7). Glutamine, and possible glutamate, exerts repression effect by activating the Ure2p repressor, which in turn inactivates $G \ln 3 p$ responsible for activating nitrogenregulated genes in S. cerevisiae (13). This may be an indication that $K$. marxianus $G D H 1$ gene, which has not been cloned to

Table 2. Effect of different carbon or nitrogen sources on the specific growth rate and NADP+-Gdh specific activity of $K$. marxianus CBS6556 cells.

\begin{tabular}{|c|c|c|c|c|c|}
\hline \multicolumn{3}{|c|}{$\begin{array}{c}\text { N-source } \\
(\text { Mineral medium }+1 \% \text { glucose })\end{array}$} & \multicolumn{3}{|c|}{$\begin{array}{c}\mathrm{C} \text {-source } \\
\text { (Mineral medium }+40 \mathrm{mM}\left(\mathrm{NH}_{4}\right)_{2} \mathrm{SO}_{4}\end{array}$} \\
\hline$(40 \mathrm{mM})$ & $\left(\mathrm{h}^{-1}\right)$ & Gdh $( \pm \mathrm{SD})$ & $(1 \%)$ & $\left(\mathrm{h}^{-1}\right)$ & Gdh $( \pm \mathrm{SD})$ \\
\hline$\left(\mathrm{NH}_{4}\right)_{2} \mathrm{SO}_{4}$ & 0.40 & $0.36(0.04)$ & Glucose & 0.40 & $0.32(0.03)$ \\
\hline Glutamate & 0.39 & $0.09(0.03)$ & Lactose & 0.42 & $0.31(0.02)$ \\
\hline Glutamine & 0.40 & $0.22(0.05)$ & Ethanol & 0.27 & $0.33(0.03)$ \\
\hline Leucine & 0.27 & $0.16(0.01)$ & Acetate & 0.13 & $0.02(0.01)$ \\
\hline
\end{tabular}


date, may have $\mathrm{UAS}_{\mathrm{LEU}}$ element in its promotor region, and may be regulated by the same regulatory pathway as $S$. cerevisiae.

The evidences presented here suggest that ammonium assimilation pathway of $K$. marxianus resembles more that of $S$. cerevisiae than its closely related specie K. lactis.

\section{ACKNOWLEDGEMENTS}

This work was supported by the Conselho Nacional de Desenvolvimento Científico e Tecnológico (CNPq) by the grant AI-524562/96-2.

\section{RESUMO}

\section{Glutamato desidrogenase dependente de $\mathrm{NADP}^{+}$da levedura Kluyveromyces marxianus responde à repressão catabólica de maneira similar à Saccharomyces cerevisiae}

Glutamato desidrogenase dependente de $\mathrm{NADP}^{+}\left(\mathrm{NADP}^{+}-\right.$ $\mathrm{Gdh}$ ) constitui o primeiro passo enzimático no mecanismo de assimilação de nitrogênio em Saccharomyces cerevisiae e o conhecimento de sua regulação é chave na iniciativa de vários propósitos biotecnológicos, tais como a produção de proteína microbiana. A regulação da atividade $\mathrm{NADP}^{+}-$Gdh em células de Kluyveromyces marxianus foi avaliada a partir de diferentes condições de suprimento de amonia em cultivo em batelada. Os resultados mostraram que a atividade $\mathrm{NADP}^{+}-\mathrm{Gdh}$ de $K$. marxianus foi induzida em uma estreita faixa de concentração de amonia no meio, sendo reprimida tanto por altas concentrações deste composto quanto pelo produto glutamato. Esta atividade não está associada ao crescimento celular e deve funcionar principalmente no rastreamento de pequenas quantidades de amonia após a parada do crescimento celular. Isto demonstra que $\mathrm{NADP}^{+}-\mathrm{Gdh}$ não deve ser a principal enzima de assimilação de amonia em $K$. marxianus, como tem sido postulado para $K$. lactis, contudo deve estar submetida ao mesmo mecanismo regulatório encontrado em S. cerevisiae.

Palavras-chave: assimilação de amônia, atividade enzimática, glutamato desidrogenase, Kluyveromyces marxianus.

\section{REFERENCES}

1. Belem, M.A.F.; Lee, B.H. Production of bioingredients from Kluyveromyces marxianus grown on whey: An alternative. Crit. Ver. Food Sci. Nutr., 38:565-598, 1998.

2. Bergemeyer, H.U. Methods of enzymatic analysis, $3^{\text {rd }}$ ed., vol. VIII. Weinheim-Verlag Chemie, Berlin, 1985.

3. Bongonez, E.; Satrustegui, J.; Machado, A. Regulation by ammonium of glutamate dehydrogenase $\left(\mathrm{NADP}^{+}\right)$from Saccharomyces cerevisiae. J. Gen. Microbiol., 131:1425-1432, 1985.

4. Cataldo, D.A.; Schrader, L.E.; Youngs, V.L. Analysis by digestion and colorimetric assay of total nitrogen in plant tissue high in nitrate. Crop Sci., 14:854-856, 1974.

5. Dubois, E.; Grenson, H. Methylaine/ammonia uptake system in Saccharomyces cerevisiae: multiplicity and regulation. Mol. Gen. Genet., 175:67-76, 1979.

6. Gonzalez-Siso, M.I.; Freire-Picos, M.A.; Ramil, E.; GonsalezDomingues, M.; Torres, A.R.; Cerdan, M.E. Respirofermentative metabolism in Kluyveromyces lactis: insights and perspectives. Enz. Microbial Technol., 26:699-705, 2000.

7. Hu, Y.; Cooper, T.G.; Kohlhaw, G.B. The Saccharomyces cerevisiae Leu3 protein activates espression of $G D H 1$, a key gene in nitrogen assimilation. Mol. Cell. Biol., 15:52-57, 1995.

8. Kiers, J.; Zeeman, A.M.; Luttik, M.A.H.; Thiele, C.; Castrillo, J.I.; Steensma, H.Y.; van Dijken, J.P.; Pronk, J.T. Regulation of alcoholic fermentation in batch and chemostat cultures of Kluyveromyces lactis CBS 2359. Yeast, 14:459-469, 1998.

9. Magazanik, B. Regulation of nitrogen utilization. In: Jones; Pringle; Broach (eds). The molecular and cell biology of the yeast Saccharomyces cerevisiae: gene expression. Cold Spring Habor Laboratory Press, Cold Spring Habor, 1992, p.283-317.

10 . Norkranz, B.; Tublad-Johanson, I. Changes in free amino acids content and activities of amination and transamination enzymes in yeast growth on different inorganic nitrogen sources, including hydroxylamine. Antonie van Leeuwenhoek, 47:217-230, 1981.

11. Oliver H.; Lowry, O.H.; Rosebrough, N.J.; Farr, A.L.; Randall, R.J. Protein measurement with the Folin phenol reagent. J. Biol. Chem., 193:265-275, 1951.

12. Romero, M.; Guzmanleon, S.; Aranda, C.; Gonzalez-Halpen, D.; Valenzuela, L.; Gonzalez, A. Pathways for glutamate biosyntheses in the yeast Kluyveromyces lactis. Microbiology, 146:239-245, 2000.

13. Ter Schure, E.G.; Silljé, H.H.W.; Raeven, L.J.R.M.; Boonstra, J.; Verrips, C.T. Nitrogen-regulated transcription and enzyme activities in continuous culture of Saccharomyces cerevisiae. Microbiology, 141:1101-1108, 1995

14. Valenzuela, L.; Guzmanleon, S.; Coria, R.; Ramirez, J.; Aranda, C.; Gonzalez, A.A NADP-glutamate dehydrogenase mutant of the petitnegative yeast Kluyveromyces lactis uses the glutamine sinthase glutamate sinthetase pathway for glutamate biosynthesis. Microbiology, 141:2443-2447, 1995.

15. Zeeman, A.M.; Kuyper, M.; Pronk, J.T.; van Dijken, J.P.; Steensma, H.Y. Regulation of pyruvate metabolism in chemostat cultures of Kluyveromyces lactis CBS 2359. Yeast, 16:611-620, 2000. 